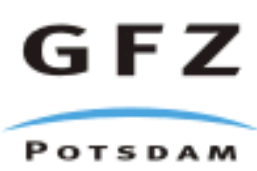

Originally published as:

Mayer, C., Lambrecht, A., Hagg, W., Helm, A., Scharrer, K. (2008): Post-drainage ice dam response at Lake Merzbacher, Inylchek glacier, Kyrgyzstan. - Geografiska Annaler, Series A: Physical Geography, 90, 1, 1-10. 


\title{
Post-drainage ice dam response at Lake Merzbacher, Inylchek glacier, Kyrgyzstan
}

\author{
BY \\ C. MAYER ${ }^{1}$, A. LAMBRECHT ${ }^{2}$, W. HAGG ${ }^{3}$, A. HELM ${ }^{4}$ AND K. SCHARRER \\ ${ }^{1}$ Commission for Glaciology, Bavarian Academy of Sciences and Humanities, Munich, \\ Germany \\ ${ }^{2}$ Institute of Meteorology and Geophysics, University of Innsbruck, Austria \\ ${ }^{3}$ Department of Geography, Ludwig-Maximilians-University, Munich, Germany \\ ${ }^{4}$ GFZ, Potsdam, Germany \\ ${ }^{5}$ Institute for Geology, Ludwig-Maximilians-University, Munich, Germany
}

Mayer, C., Lambrecht, A., Hagg, W., Helm, A. and Scharrer, K. : Geogr. Ann.,

\begin{abstract}
The Inylchek glacier system in Central Tian Shan, Kyrgyzstan, comprises a large glacier dammed lake which usually drains once a year through a subglacial drainage system. Detailed GPS measurements on the ice dam and the analysis of Aster scenes from several subsequent years now provide insight into the post-drainage dam response and the changed ice dynamic conditions. We could demonstrate that during high water levels in the lake a large part of the ice dam becomes afloat, lifting the ice surface up to almost $20 \mathrm{~m}$ in the central dam region. During this phase of extensive floatation strong calving is facilitated, which is supported by the high density of ice debris in the lake. In general, surface ice velocities are about 1.5-2 times higher during summer than in winter. Closer to the lake, however, ice velocities increase considerably after the drainage event, showing values more than 3 times the annual mean. The increased mass flux during the phase of high lake level needs to be compensated by replenishment of the lost ice from the dam. Therefore the ice velocities show compressive flow during the remaining part of the year. These results show a strong influence of Southern Inylchek glacier by the existence of the lake.
\end{abstract}

\section{Introduction}

Glacier lake outburst floods (GLOF) are one of the major hazards related to the existence of alpine-type glaciers. In most cases moraine-dammed lakes or intra-glacially stored water form the source of such floods after failure of the respective dam. In some rare cases water is also retained in lateral valleys if a glacier fills out the main valley. In contrast to moraine-dammed lakes which usually are drained continuously by a spillway, ice-dammed lakes in lateral valleys release their water along the lateral moraine of the glacier, or through the glacier itself. In the latter case deformation of the glacier ice can close the passageways and the lake basin fills until the water level is high enough to create another outlet. Depending on the individual conditions, the outlet can extend very quickly in size, enabling the creation of a GLOF (e.g. Nye 1976, Björnsson 1992, Mayer and Schuler 2005).

Lake Merzbacher is a prominent example of an ice-dammed lake, occupying the lower end of a tributary valley of Southern Inylchek glacier, central Tian Shan. There, GLOFs occur regularly at least once every summer, draining major amounts of the lake water (Glazirin and Kagan, 1986). The drainage can exceed $1000 \mathrm{~m}^{3} / \mathrm{s}$ and the floods usually last for several days and up to two weeks, before the lake is empty or the subglacial passages are closed again (Mavlyudov 1999). As these floods occur periodically, only the large ones generate considerable damage at downstream infrastructure. 
DRAFT REV. 1 of Mayer, C., Lambrecht, A., Hagg, W., Helm, A., Scharrer, K. (2008): Post-drainage ice dam response at Lake Merzbacher, Inylchek glacier, Kyrgyzstan. - Geografiska Annaler, Series A: Physical Geography, 90, 1

Southern Inylchek glacier is strongly influenced by the existence of the lake. A large part of the ice flux is transported towards the lake forming an ice dam, instead of following the main valley to the glacier terminus. The ice dam acts as a calving front, especially during high lake levels, when large amounts of ice detach from the glacier and float in the lake. The influence of the lake on the glacier and especially the relation between ice flow and variations in lake levels are the focus of this paper.

\section{Physical setting of the glacier/lake system}

The central Tian Shan mountains are heavily glacierised and some of the largest non-polar glacier systems worldwide can be found here. Southern Inylchek glacier together with Northern Inylchek glacier, drain an area of more than $800 \mathrm{~km}^{2}$. Moraine deposits on the lower valley slopes stretching from Southern to Northern Inylchek glacier clearly indicate an earlier continuous glaciation. The glaciers separated probably during the glacier recession in the second half of the $19^{\text {th }}$ century, as is also proposed by Glazirin and Popov (1999).

Subsequently a lake formed at the lower end of the Northern tributary valley by accumulation of melt water, blocked by the ice of Southern Inylchek glacier. This lake (now known as Lake Merzbacher) was first visited and described by G. Merzbacher in 1903, who estimated the width of the lake at the glacier dam to be $1.1 \mathrm{~km}$ and a length of the lake of $4 \mathrm{~km}$ (Merzbacher 1905). This lake extent was close to the present maximum extent, before the onset of drainage (Mavlyudov 1996).

The Northern Inylchek glacier front is now located several kilometres up-valley and has created a pro-glacial lake in the bounds of a former terminal moraine. The melt water from this glacier passes through the pro-glacial lake and drains into Lake Merzbacher. Southern Inylchek glacier forms the dam for Lake Merzbacher, preventing the water from direct run-off into the main valley. The generation of the lake also had serious consequences for the dynamic regime of Southern Inylchek glacier. A major part of the ice flow is diverted, entering the lake instead of following the direction of the main valley.

Southern Inylchek glacier covers an area of $488 \mathrm{~km}^{2}$ and has a maximum length of about 60 $\mathrm{km}$, as derived from the analysis of several Aster scenes of this area. The width of Southern Inylchek glacier is about $1.9 \mathrm{~km}$ at a cross section $1.5 \mathrm{~km}$ upstream of Merzbacher meadow (see Fig. 1).

\section{Field measurements}

\section{Data and Methods}

In July and August 2005 field work was carried out on the ice dam and adjacent areas of Southern Inylchek glacier, where ice ablation and surface velocities were measured. For detecting temporal variations in glacier elevation and horizontal surface movement, a network of 22 ablation stakes on one longitudinal and two cross profiles (Fig. 2 and Hagg et al., this volume, submitted) was repeatedly surveyed with differential GPS. The base station for the differential processing was installed at a reference point on Merzbacher Meadow, which was already used for GPS surveys earlier (reference position: $42^{\circ} 09^{\prime} 55.76^{\prime}$ N, $79^{\circ} 49^{\prime} 01.38$ ” E, 3402.64 m, pers. com. H.U. Wetzel, August 2006). In addition, reference data from IGS (International GNSS Service) stations were used for accurate geo-referencing of the local network (CHUM: Chumysh in Kazakstan, POL2: Bishkek in Kyrgyzstan and SELE: Almaty in Kazakstan). The usual occupation time at the stakes was about 15 minutes using a single frequency L1 differential receiver and the baseline distance varied between $220 \mathrm{~m}$ and 2600 $\mathrm{m}$. With this setup post-processing accuracies for the stake locations of $\pm 5 \mathrm{~cm}$ in the horizontal and $\pm 25 \mathrm{~cm}$ in the vertical could be reached. All stakes were occupied at least twice with a time difference between five and eleven days (for specific dates see Table 1), resulting 
DRAFT REV. 1 of Mayer, C., Lambrecht, A., Hagg, W., Helm, A., Scharrer, K. (2008): Post-drainage ice dam response at Lake Merzbacher, Inylchek glacier, Kyrgyzstan. - Geografiska Annaler, Series A: Physical Geography, 90, 1

surface ice velocities for this time period. Changes in elevation were measured at the top level of the stakes, separating ablation (measured change in stake height above the ice) from vertical ice movement (variation of the stake elevation). Considering the measured horizontal displacement and the local surface slope, the vertical component of the surface velocity can be calculated in order to distinguish between local flow and vertical surface changes not directly connected to the local flow.

\section{Results}

Horizontal and vertical displacements of the ablation stakes resulting from these calculations are shown in Table 1 . The derived horizontal velocity during the field work period varies between $0.15 \mathrm{~m} / \mathrm{d}$ (ABL01; $55 \mathrm{~m} / \mathrm{yr}$ ) and $0.79 \mathrm{~m} / \mathrm{d}$ (ABL21; $288 \mathrm{~m} / \mathrm{yr}$ ), respectively. The velocity distribution at the upstream cross profile (ABL01 - ABL08) show a typical velocity distribution, where the velocities close to the glacier margin are about $74 \%$ of the maximum surface velocity almost at the centre of the glacier. There is no indication for an increased ice transport towards the lake in this region. On the contrary, the velocities towards the lake are $18 \%$ lower than the velocities in the flow band directed towards the glacier front. Downstream of the cross-profile the surface slope steepens towards the ice dam (from ABL07 to ABL12) resulting in an increase of the ice surface velocity by a factor of 2.3. Although the surface slope decreases strongly between stakes ABL12 and ABL 15, the surface velocity increases further by a factor of 1.35. This continued velocity increase in the flatter region, downstream of ABL12, indicates a growing influence of basal processes for the glacier movement in this part of the glacier.

At the lower cross profile (ABL18 - ABL22) the surface velocity increases from the inner part of the bend in glacier flow towards to outer part. Stake ABL22 shows a lower velocity and a rotation in flow direction away from the ice dam which indicates that this part of the glacier is outside the flow band into Lake Merzbacher. This can also be expected from the analysis of flow bands on the available Aster satellite image.

Vertical displacements are measured as true vertical ice movement without the contribution from ablation, as described above. Along the longitudinal profile the observed vertical displacement is about 2 - 4 times higher than the vertical component of the surface velocity for the stakes ABL07, ABL09 and ABL10 (Table 1). These deviations could be explained by uncertainties in the local surface slope and errors in the GPS measurements. At ABL11 the observed vertical displacement is already 5 times higher than the vertical surface velocity and this factor increases to almost 50 at stake ABL13. Similar conditions exist for the stakes of the lower cross profile, where the local slope is similar to the slope at stake ABL14 (which gives e.g. a factor of 58 for the ratio of vertical displacement to vertical surface velocity at stake ABL20). This analysis demonstrates that the vertical displacement in the ice dam region downstream of stake ABL11 cannot be explained by normal glacier flow alone. The maximum vertical displacement rate observed in this area was $-15.9 \mathrm{~m}$ over a period of 9 days at stake ABL14.

\section{Remote sensing}

\section{Data and methods}

In order to extend the velocity analysis over a longer period, satellite images were used for the detection of horizontal surface velocities. In high resolution imagery the displacement of stable features can be detected and related to the glacier surface velocity (e.g. Kääb, 2005). The Aster sensor onboard the Terra satellite provides images with a spatial resolution of $15 \mathrm{~m}$ in the visible bands which allows the determination of surface displacements for stable features identifiable in the image. For Inylcheck glacier suitable Aster images are available for the years 2003 ( $25^{\text {th }}$ June and $29^{\text {th }}$ September), 2004 (1 $1^{\text {th }}$ June) and 2005 (29 $9^{\text {th }}$ May), 
DRAFT REV. 1 of Mayer, C., Lambrecht, A., Hagg, W., Helm, A., Scharrer, K. (2008): Post-drainage ice dam response at Lake Merzbacher, Inylchek glacier, Kyrgyzstan. - Geografiska Annaler, Series A: Physical Geography, 90, 1

where no cloud or snow cover obstructs the ice dam region. We used the Aster image of $25^{\text {th }}$ June 2004 as master and generated co-registered images from the other available scenes with the GCPworks tool of the GEOMATICA software package. Based on these data it is possible to generate displacement maps for two annual periods (2003/2004 and 2003/2005) and seasonal maps for the summer 2003 and the winter 2003/2004. For this purpose we used the feature tracking software IMCORR (Scambos et al. 1992) which uses a fast Fourier-transform version of the normalised cross-covariance method for determining the maximum correlation between two images resulting in sub-pixel accuracy of the feature displacement. Features used for this analysis are temporally stable disturbances of the glacier surface like e.g. crevasses, debris patterns or other semi-permanent lakes.

\section{Error estimation for the displacement analysis}

Potential errors of the horizontal displacements deduced from remote sensing imagery are influenced by the correct co-registration of the images and the algorithm which is used for calculating local displacement.

For determining surface displacements only the relative change of features from one image to another is of interest in this study which makes it important to generate accurate co-registered images on a master scene. Due to the rather constant orbit parameters for the same track and frame location, the distortion between the individual images is rather small. A cross-check of stable non-glacier pixels between the images resulted in correlation errors of less than one pixel. The shift of identified features from one image to another represents a combination of surface elevation change and slope parallel surface movement. With the given image geometry of the Aster scene a vertical displacement of $10 \mathrm{~m}$ will result in a horizontal shift of $0.44 \mathrm{~m}$ for the largest local incidence angle. This is much less than the pixel dimension. In contrast, the largest observed displacements between the individual satellite images are in the order of $100 \mathrm{~m}$ (or 6-7 pixels). Even for the steepest slopes in the region of the ice dam, the elevation difference is less than $25 \mathrm{~m}$ over this distance, which would correspond to a maximum position error of about $1 \mathrm{~m}$. Compared to the observed feature displacements this is in the order of $1 \%$. Therefore, orthorectification with an elevation model of uncertain accuracy will not increase the quality of the analysis in this case.

Another error source of the determined surface displacement results from the image correlation itself. The accuracy of the surface velocity field derived from every image pair by the IMCORR software mainly depends on the co-registration and the time separation of the images. The total error $\sigma_{v}$, computed as the standard deviation of the offset values, consists of the systematic $\sigma_{\text {syst }}$ and the random error $\sigma_{\text {rand }}$ (Berthier et al. 2003):

$$
\sigma_{v}=\sqrt{\sigma^{2} \text { syst }+\sigma^{2} \text { rand }}
$$

The systematic error $\left(\sigma_{\text {syst }}\right)$ corresponds to the accuracy of co-registration of each ASTER pair. Co-registration was performed by manual ground control point (GCP) measurement in the ice-free areas of the respective image pairs. Subsequent control of the position accuracy of measured GCPs revealed an error value of maximum one pixel $(15 \mathrm{~m})$.

The cross-correlation inherent random error $\left(\sigma_{\text {rand }}\right)$ can be determined by the error estimations for $\mathrm{x}$ - and $\mathrm{y}$-offsets listed in the IMCORR output file. It varies between $0.13-0.15$ pixels in the correlation results. Now, calculating $\sigma_{\mathrm{v}}$ with the above equation a total error between 1.061.07 pixels is derived for all correlation pairs. This corresponds to $0.16 \mathrm{~m} \mathrm{~d}^{-1}$ for the image pair 25/06/03 - 29/09/03 and is reduced to $0.04 \mathrm{~m} \mathrm{~d}^{-1}$ for the image pairs 25/06/03 - 11/06/04 and 11/06/04 - 29/05/05, due to the longer interval. 
DRAFT REV. 1 of Mayer, C., Lambrecht, A., Hagg, W., Helm, A., Scharrer, K. (2008): Post-drainage ice dam response at Lake Merzbacher, Inylchek glacier, Kyrgyzstan. - Geografiska Annaler, Series A: Physical Geography, 90, 1

\section{Results}

From the remote sensing data analysis, the mean annual surface velocity is $80-90 \mathrm{~m} / \mathrm{yr}$ at a cross-profile about $2 \mathrm{~km}$ upstream of Merzbacher meadow ( $M$ in Fig. 1). Thus, assuming a typical vertically averaged horizontal velocity of $80 \%$ of the surface velocity, the annual ice flux from the upper regions of Inylchek glacier is about $0.02 \mathrm{~km}^{3}$ through this profile. According to our flow line analysis in this region, $1.1 \mathrm{~km}$ of the glacier width (or $58 \%$ of the glacier) drain into the lake. Across the transect, which corresponds to seismic profile 5 in Macheret et al. (1993), the mean ice thickness is about $160 \mathrm{~m}$, which results in a cross section area of $0.3 \mathrm{~km}^{2}$. Thus, the mean annual ice transport towards the ice dam is $0.012 \mathrm{~km}^{3}$ which corresponds to roughly 7\% of the estimated maximum lake volume (Mavlyudov 1996).

The displacement maps from the IMCORR analysis (Fig. 3) show the typical surface velocity pattern of valley glaciers with the highest velocities in the centre of the glacier and a strong gradient towards the margins. However, it is also obvious that the main ice flux turns towards the lake, whereas ice transport further down-valley is strongly reduced. From the right hand side of Figure 1 the surface velocity slowly decreases down-stream, as can be expected for parallel ice flow in the ablation zone. In contrast, close to the calving front acceleration is observed which is in accordance with the enhanced mass flux due to calving of ice into the lake. The typical surface velocities at the centre of the glacier are in the order of $0.25-0.35$ $\mathrm{m} / \mathrm{d}(90-130 \mathrm{~m} / \mathrm{yr})$ over the observation period. After the turn of the glacier towards the lake, the velocities are larger on the right part of the glacier, than on the left. The right part also shows an ice tongue protruding further into the lake on several images. If this is due to the higher velocities or a different bathymetry in this area is not known. The increased ice transport towards the far side of the intersection between the main valley and Lake Merzbacher (left side of the glacier part draining into the lake) very probably creates a convergent flow of ice which results in lower velocities.

For the further analysis, surface velocities were extracted from all displacement maps for the upper cross profile and the longitudinal profile of the stake network (profiles b and $c$ in Fig. 3), as well as for a cross profile just downstream of the intersection (profile a in Fig. 3). A direct comparison of the surface velocities derived from the Aster images shows that the general distribution is rather time conservative (Fig. 4). At profile a) velocities are lower close to the southern margin than in the North due to less ice transport along the southern flow bands. Profile b) shows a typical cross-section velocity distribution with a 2-3 times higher velocity at the glacier centre compared to the margins. Also along the longitudinal profile c) the typical decrease of ice velocities in downstream direction can be seen until about one kilometre before the calving front.

The summer velocities (end of June until end of September) are generally about a factor 1.5 2 higher than the annual velocities, whereas winter velocities (end until September to mid of June) are about $0.8-0.9$ times the annual velocities. The annual velocities are generally slower in 2004/2005 compared to the year before and the largest discrepancies occur in the ice transport towards the lake. In cross-section b) (Fig. 4) the right part of the profile shows surface velocities for 2004/2005 up to 30\% lower than the preceding year. Along the longitudinal profile it becomes obvious that the difference in surface velocity increases towards the calving front, indicating some influence of the lake - ice dam interaction on the general ice velocity distribution in this area. Unfortunately no hydrograph is available for these years which would allow a closer investigation. The onset of the lake drainage occurred roughly at the same time in 2004 and 2005 (6./7. August and 13./14. July, respectively), which does not give any indication for considerable differences in drainage magnitude or mechanism. However, it is interesting to note that the winter velocities on the ice dam (Distance 0 - $2000 \mathrm{~m}$ on profile c) in 2003/2004 are even higher than the annual velocities 2004/2005. This indicates that in 2004 either the level of the lake was not as high as in the 
DRAFT REV. 1 of Mayer, C., Lambrecht, A., Hagg, W., Helm, A., Scharrer, K. (2008): Post-drainage ice dam response at Lake Merzbacher, Inylchek glacier, Kyrgyzstan. - Geografiska Annaler, Series A: Physical Geography, 90, 1

previous year, reducing the degree of floatation and thus the mobilisation of ice in the ice dam; or the duration of a high lake level was shorter and therefore not as much ice, calving into the lake, had to be replenished after the drainage period. The fact that the annual velocities from September to September of the subsequent year always include the reaction from two drainage events (the drainage during the actual period and the drainage just before the period starts) even complicates the interpretation of these results.

\section{Response analysis}

\section{Horizontal displacements}

The results from the remote sensing analysis show that there is a clear seasonality in the ice movement of Southern Inylchek glacier. Also the existence of Lake Merzbacher has a considerable influence on the velocity pattern of the larger ice dam region. This is in contrast to smaller ice contact lakes, where the deviation of ice flow is only noticeable during periods of high water level (e.g. Sugiyama et al., 2007, Walder et al., 2006). Ice is diverted from the main glacier direction towards the calving front at the lake.

The GPS measurements were made immediately after the beginning of the first drainage event in 2005. In that year there were two drainage events, where a smaller event followed the main outburst about two weeks later. The GPS derived surface velocities were determined during the period between the two drainage events, providing the direct dynamic answer of the ice dam to the first drainage. From the GPS measurements along cross profile b) in Figure 4 it is obvious that the region further away from the ice dam is not yet influenced by the lake at all. Neither floatation of ice and increased calving, nor higher velocities due to enhanced basal sliding during the flooding seem to reach as high as the location of that profile. This is also emphasised by the fact that the results from the GPS measurements are rather close to the annual mean velocities from feature tracking. The region, however, shows some reaction resulting in higher velocities (up to 30\% higher than the annual mean) on a longer timescale, as can be seen from the summer velocities in 2003. The velocities are derived from images which cover a longer period of 96 days and, more important, two months following the lake drainage. This indicates that within the two months after the drainage occurred, this part of the glacier experienced higher ice velocities towards the calving front. The ice mass which is lost in the period of intensive calving, when the lake level reaches its maximum, will be replenished by an increase in ice flux which subsequently reaches areas further upstream. The direct reaction to the high calving flux can be observed in the longitudinal profile, where the GPS based velocities are decidedly higher than velocities determined over longer time spans. The first two kilometres from the calving front show velocities up to 3 times higher than the annual mean velocities and still 1.7 times higher than the summer velocities in 2003. Between stakes ABL11 and ABL07 there is a sharp drop in the surface velocity which coincides with a step-like increase in glacier elevation (about $50 \mathrm{~m}$ elevation change within $450 \mathrm{~m}$ horizontal distance). This step in the surface profile also represents a strong change in ice thickness from more than $300 \mathrm{~m}$ thick ice in the lower ice dam region to ice thicknesses around $180 \mathrm{~m}$ further upstream (Macheret et al. 1993). Because of this geometry the higher parts of the glacier above ABL11 are not directly influenced by the filling of the lake. However, due to the increased mass flux towards the ice front also these regions experience an increase in ice velocities some weeks after the maximum lake level was reached. Regarding the annual surface velocities along the longitudinal profile, it is obvious that the pattern is opposite to the GPS derived velocities between $500 \mathrm{~m}$ and $2 \mathrm{~km}$ from the calving front (Fig. 4c). From about $2.5 \mathrm{~km}$ downstream the long term velocities decrease, which can be explained by a re-thickening of the glacier, after the mass loss due to calving during the period of high lake level. 
DRAFT REV. 1 of Mayer, C., Lambrecht, A., Hagg, W., Helm, A., Scharrer, K. (2008): Post-drainage ice dam response at Lake Merzbacher, Inylchek glacier, Kyrgyzstan. - Geografiska Annaler, Series A: Physical Geography, 90, 1

\section{Vertical displacements}

The GPS measurements of the vertical stake displacement (Tab. 1) show a pattern which confirms the spatial influence of the lake filling on the ice dam. All stakes of the cross profile b) and the stakes upstream of stake ABL11 show rather small vertical displacements of less than $10 \mathrm{~cm} / \mathrm{d}$ which can be explained by the vertical component of the normal glacier movement. Downstream of ABL11 and towards the calving front, however, the vertical displacements increase strongly, reaching a maximum value of $-1.77 \mathrm{~m} / \mathrm{d}$ at stake ABL20. For these stakes the observations stretched over a period of 9 days, starting at the $1^{\text {st }}$ of August, resulting in total vertical displacements between -3.5 m (ABL11) and -17.7 m (ABL20) with a mean value of $-10.4 \mathrm{~m}$. Such high values cannot be explained by an ice dynamic reaction following floatation and drainage. Using a simple spreading model for floating ice tongues (Hooke, 2005), the change in ice thickness due to uniaxial spreading would be roughly $6 \mathrm{~m} / \mathrm{yr}$ for a floating tongue of $300 \mathrm{~m}$ thickness. This mechanism would at most contribute only about $15 \mathrm{~cm}$ to the observed change in surface elevation. Most likely the entire ice dam became afloat during the filling of the lake up to approximately stake ABL12. All stakes on the longitudinal profile downstream of stake ABL12 show very similar vertical displacements, demonstrating a rather uniform vertical movement of the glacier. Between ABL12 and ABL07 the vertical movement reduces from $-6 \mathrm{~m}$ to $-0.6 \mathrm{~m}$ during the period of observation, which indicates a likely position of the temporary grounding line in this region. This means that during times of high lake levels almost $1.6 \mathrm{~km}$ of the ice dam becomes afloat. The steeper slope of the bedrock between ABL12 and ABL07 (increase in bedrock elevation of about170 m, according to Macheret et al., 1993) prevents the upstream glacier to become afloat as well.

Observations of the lake level during the same time period (Helm et al., 2006) showed that after the first drainage event the lake slowly refilled with measured rates of about $2-4 \mathrm{~cm} / \mathrm{h}$ in elevation change between $28^{\text {th }}$ July and $31^{\text {st }}$ July. During the $31^{\text {st }}$ July a second dam failure happened, resulting in a drop of the lake surface of almost $14 \mathrm{~m}$ within the first 4 days. On the lower cross section (Fig. 2), the vertical displacement increases from the East towards the West, reaching the highest values at the stakes ABL20 and ABL21. The reason for this stronger elevation loss (almost double the values of the eastern part) could be the existence of the subglacial drainage system in this area. A similar interpretation was given by Sugiyama et al. (2007) for observed surface elevation changes at Gornergletscher, Switzerland. Strong subglacial water flow results in enhanced ice melt by dissipation energy and thus the generation of a cavity system. These cavities would reduce in size as soon as the water pressure reduces after the climax of the lake drainage (Nye, 1976).

\section{Conclusions}

The ice flow of Southern Inylchek Glacier is strongly influenced by the existence of Lake Merzbacher. When the lake fills with water from rainfall and glacier melt, the adjacent ice margin turns into a calving front. Due to the mass loss into the lake, ice velocities start to increase and more ice is directed towards the lake. Our measurements show that a considerable part of the glacier becomes afloat before the lake starts to drain. The fast glacier reaction directly following the lake drainage demonstrates that the lower part of the ice dam was afloat during high lake levels. The area of floating ice is probably changing from year to year, with a typical value of about $1.8 \mathrm{~km}^{2}$. The size of the floating tongue is controlled by the steep bedrock step in the vicinity of stake ABL12. This is a considerable part of the ice dam and the values of elevation change during the post-drainage period in 2005 suggest that the water column underneath the glacier reaches up to at least 17.7 metres, close to the ice front where no measurements exist probably considerably more. The mobilisation of ice requires several weeks from the beginning of floatation until also the adjacent parts of the glacier show 
DRAFT REV. 1 of Mayer, C., Lambrecht, A., Hagg, W., Helm, A., Scharrer, K. (2008): Post-drainage ice dam response at Lake Merzbacher, Inylchek glacier, Kyrgyzstan. - Geografiska Annaler, Series A: Physical Geography, 90, 1

higher ice velocities. During the winter the loss of ice in the ice dam is than replenished which is documented by the slower ice velocities and thus compressive flow in that region. Our measurements and conclusions thus support the already proposed drainage mechanism, where the ice dam experiences widespread floatation before the actual drainage is initiated.

\section{Acknowledgements}

The support by GFZ in Potsdam, especially H.U. Wetzel and A. Reigber, for enabling our participation in the expedition to Inylchek Glacier in 2005 is gratefully acknowledged. Also we are thankful for the support in many kinds of ways by W. Michajljow and the staff of CAIAG in Bishkek, Kyrgyzstan.

\section{Authors}

Dr. Christoph Mayer, Commission for Glaciology, Bavarian Academy of Sciences, AlfonsGoppel-Str. 11, 80539 Munich, Germany.

Dr. Astrid Lambrecht, Institute for Meteorology and Geophysics, University of Innsbruck, Innrain 52, 6020 Innsbruck, Austria.

Dr. Wilfried Hagg, Department of Geography, University of Munich, Luisenstr. 37, 80333 Munich, Germany.

Achim Helm, GeoForschungsZentrum Potsdam, Telegrafenberg, 14473 Potsdam.

Kilian Scharrer, Institute for Geology, University of Munich, Luisenstr. 37, 80333 Munich, Germany.

\section{References}

Berthier, E., Raup, B., Scambos, T. , 2003: New velocity map and mass-balance estimate of Mertz Glacier, East Antarctica, derived from Landsat sequential imagery.- J Glaciol. , 49: 503-511.

Björnsson, H., 1992: Jökulhlapus in Iceland: prediction, characteristics and simulation. Ann. Glaciol. 16: 141-146.

Glazirin, G. E. and Kagan, A. G., 1986: Raschet gidrologicheskih harasteristik proryva ozera Mercbahera. (Calculation of hydrological characteristics of Merzbacher Lake outburst). SANII Proceedings 111(192): 36-43.

Glazirin, G.E. and Popov, V.I., 1999: Northern Inyl'chek Glacier in the last 150 years. Mat. Glyats. Issled., 87: 165-168, (in Russian).

Hagg, W., Mayer, C., Lambrecht, A. and Helm, A., submitted: Sub-debris melt on Southern Inylchek glacier, central Tien Shan. Geogr. Ann., submitted to this volume.

Helm, A., Wetzel, H.-U., Michajljow, W., Beyerle, G., Reigber, Ch., Rothacher, M., 2006: Monitoring the 2005 dam failure event of Merzbacher glacier lake with ground-based observations of reflected GPS signals. 3rd General Assembly European Geosciences Union (Vienna, Austria 2006) 2006. Geophys. Res. Abs., 8, 02358. 
DRAFT REV. 1 of Mayer, C., Lambrecht, A., Hagg, W., Helm, A., Scharrer, K. (2008): Post-drainage ice dam response at Lake Merzbacher, Inylchek glacier, Kyrgyzstan. - Geografiska Annaler, Series A: Physical Geography, 90, 1

Hooke, R.LeB. 2005: Principles of Glacier Mechanics, Cambridge Univ. Press, Cambridge, $429 \mathrm{pp}$.

Kääb. A. 2005: Combination of STRM3 and repeat ASTER data for deriving alpine glacier flow velocities in the Bhutan Himalaya, Rem. Sens. of Envir., 94: 463-474.

Macheret, Yu. Ya., ,Ja., Nikitin, S. A., Babenko, A.N., Vesnin, A. V., Bobrova, L. I. and Sankina, L. V., 1993: Tolshchina i stroenie lednika Juzhnyj Inyl'chek po dannym radiozondirovanija (Thickness and structure of Southern Inylchek Glacier from the data of radio echo sounding). Mat. Glyats. Issled., 77: 86-97.

Mavlyudov, B. R., 1996: Drenag lednikovo-podprudnogo ozera Mercbahera (Drainage of the Mertsbakher ice-dammed lake). Mat. Glyats. Issled. , 80: 47-53.

Mavlyudov, B. R., 1999: Lednik Inylchek i ozera Mercbahera. Sostojanie 1997 godu. (Inylchek glacier and Mertsbakher Lake in 1997). Mat. Glyats. Issled. , 86: 142-148.

Mayer, C. and Schuler, T., 2005: Breaching of an ice-dam at Qorlortorsuaq tasia, South Greenland. Ann. Glaciol. , 42:297-302.

Merzbacher, G., 1905: The Central Tian-Shan mountains. 1902-1903. E.P. Dutton and Company, New York, 294 pp.

Nye, J.F., 1976: Water flow in glaciers: jökulhlaups, tunnels and veins. J. Glaciol. 17: 181207.

Scambos, T. A., M. J. Dutkiewicz, J. C. Wilson, and Bindschadler, R.A., 1992: Application of image cross-correlation to the measurement of glacier velocity using satellite image data. Remote Sensing Environ., 42(3), 177-186.

Sugiyama, S., A. Bauder, P. Weiss and Funk M., 2007: Reversal of ice motion during the outburst of a glacier-dammed lake on Gornergletscher, Switzerland, J. Glac., 53(181): 172-180.

Walder, J.S., D.C. Trabant, M. Cunico, A.G. Fountain, S.P. Anderson, R.S. Anderson and Mann A., 2006: Local response of a glacier to annual filling and drainage of an icemarginal lake, J. Glac. 52(178): 451-463. 


\section{Figures}

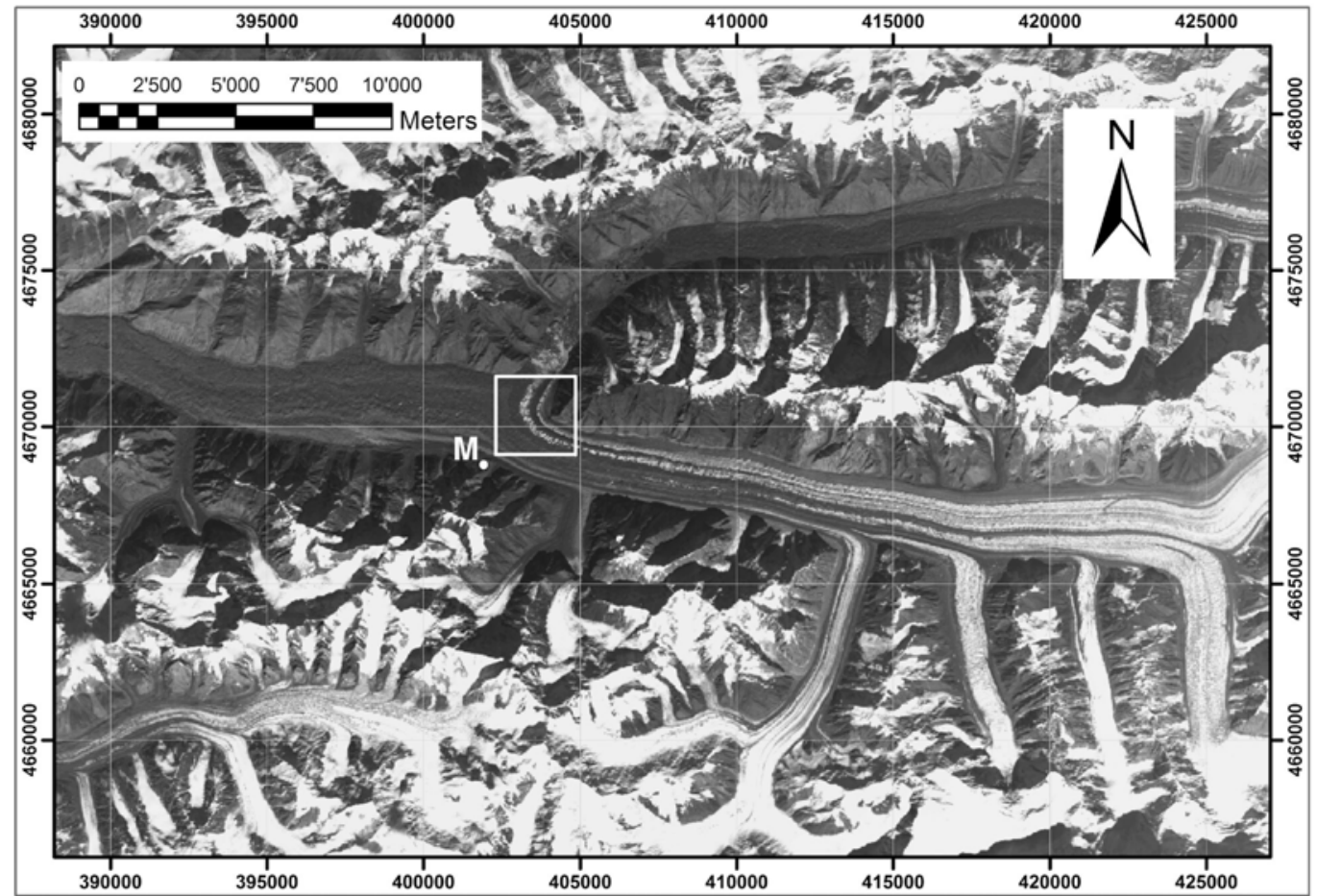

Fig. 1. Map of the ice dam region, including Merzbacher meadow (M) in the South. The rectangle indicates the area of investigation just South of Merzbacher Lake. Coordinates are given in UTM (zone 44N). The glacier tongue is just outside the map to the left.

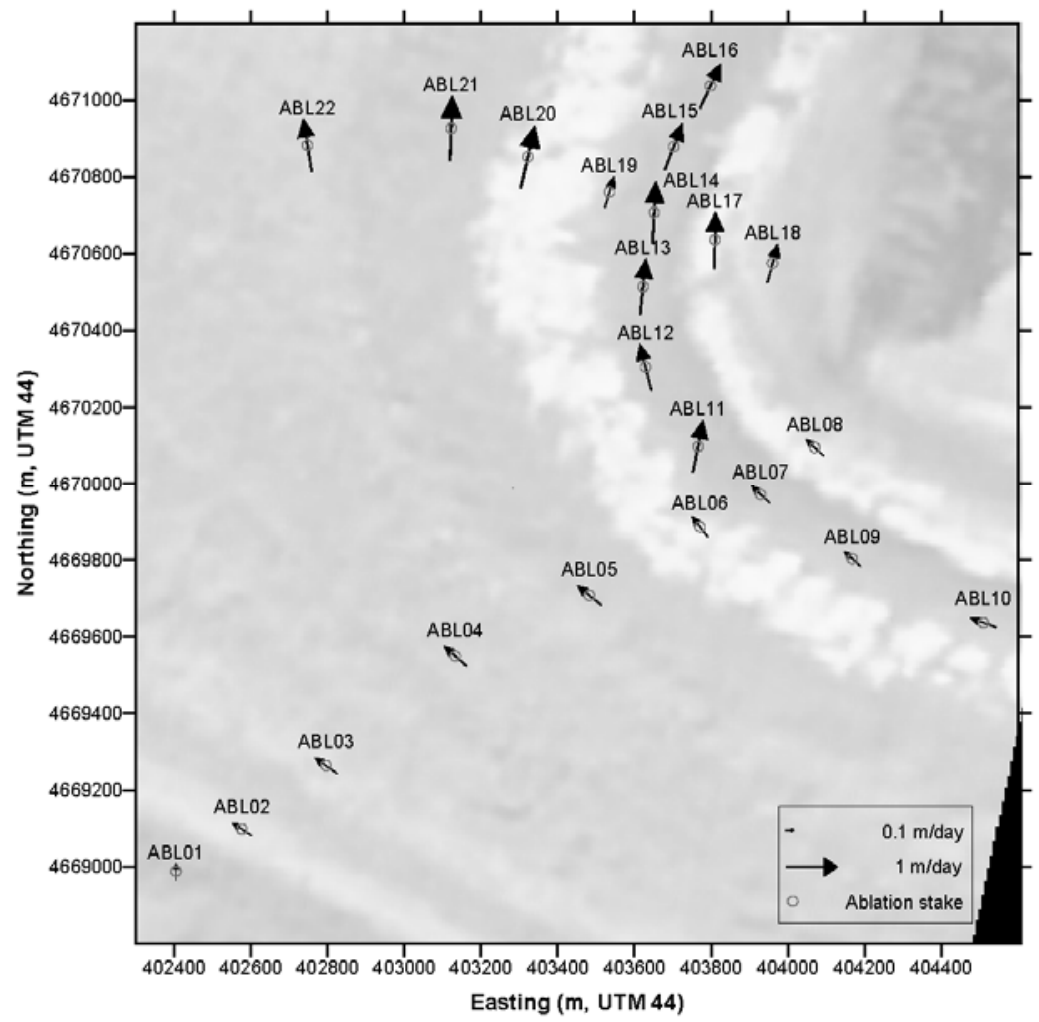

Fig. 2. Location of the stake profiles on Southern Inylchek Glacier showing the positions of the stakes as circles and the horizontal surface velocities observed as arrows. 


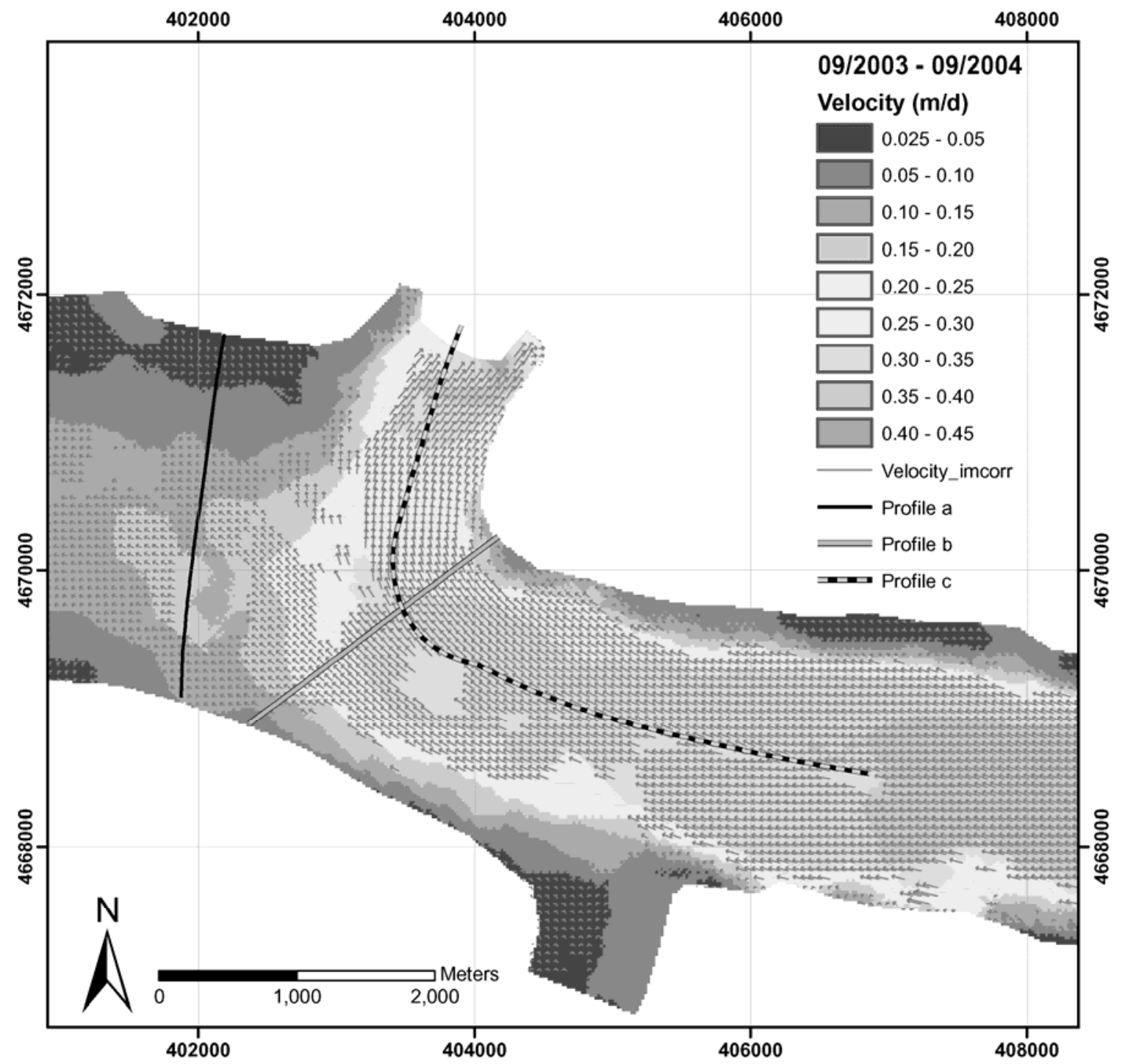

Fig. 3. Surface displacement map of central Inylchek glacier for the period June 2003 to June 2004. The map was interpolated from the feature tracking results obtained by IMCORR displayed as green arrows. The three profiles indicate the locations for displacement comparison in Fig. 4. 
DRAFT REV. 1 of Mayer, C., Lambrecht, A., Hagg, W., Helm, A., Scharrer, K. (2008): Post-drainage ice dam response at Lake Merzbacher, Inylchek glacier, Kyrgyzstan. - Geografiska Annaler, Series A: Physical Geography, 90, 1
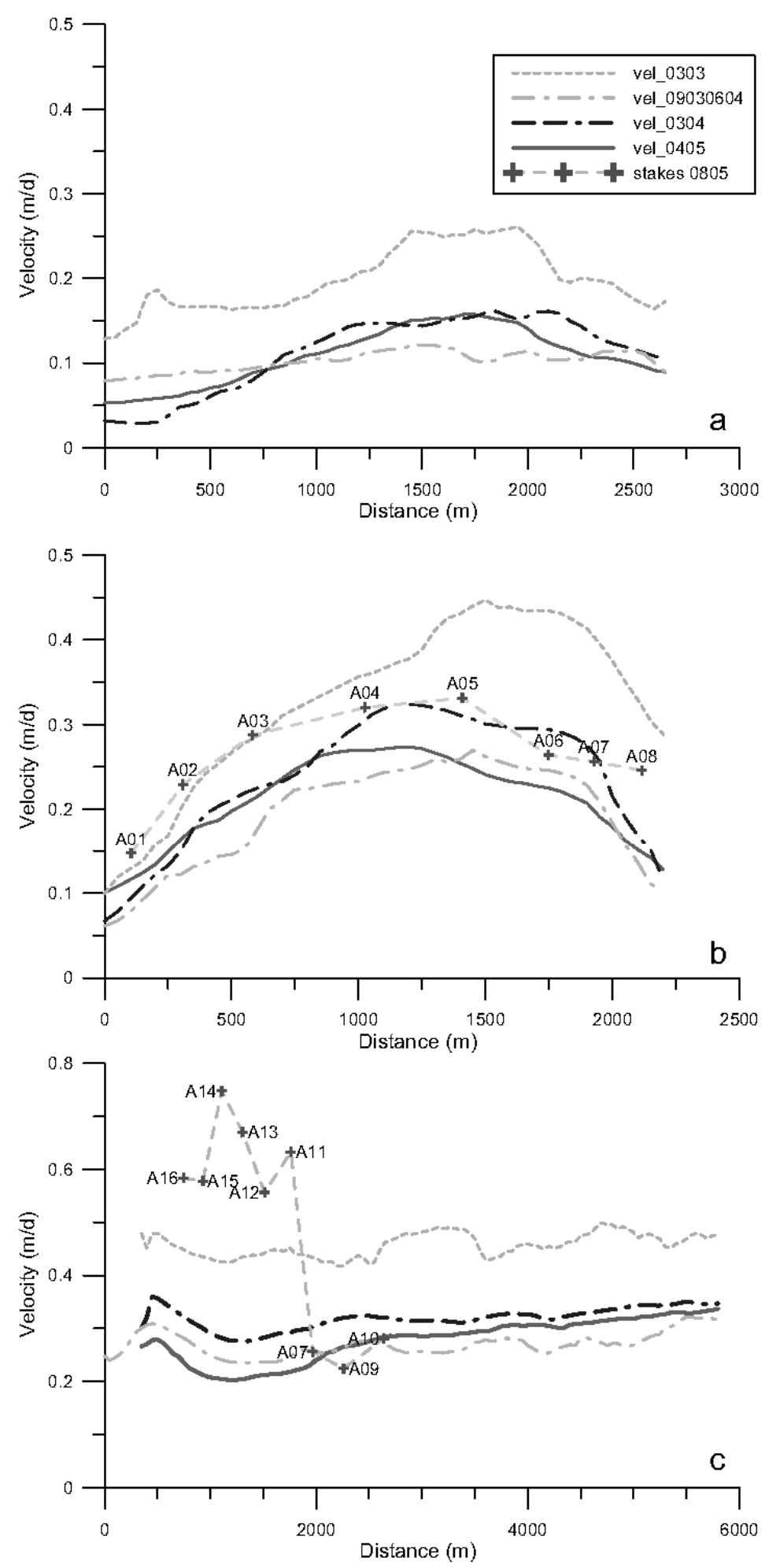

Fig. 4. Surface velocities derived from repeat Aster imagery by IMCORR analysis along the three profiles indicated in Figure 3. For the profiles b) and c) also the available surface velocities derived by GPS measurements at stakes (crosses) are shown. 
DRAFT REV. 1 of Mayer, C., Lambrecht, A., Hagg, W., Helm, A., Scharrer, K. (2008): Post-drainage ice dam response at Lake Merzbacher, Inylchek glacier, Kyrgyzstan. - Geografiska Annaler, Series A: Physical Geography, 90, 1

\section{Tables}

Table 1. Horizontal and vertical displacements of the stakes, scaled to $\mathrm{m} / \mathrm{d}$.

\begin{tabular}{|c|c|c|c|}
\hline Stake & Date & $\begin{array}{c}\text { Hor. } \\
\text { Displacement } \\
(\mathrm{m} / \mathrm{d})\end{array}$ & $\begin{array}{c}\text { Vert. } \\
\text { Displacement } \\
(\mathrm{m} / \mathrm{d})\end{array}$ \\
\hline ABL01 & $30 / 07-08 / 08$ & 0.147 & -0.021 \\
\hline ABL02 & $30 / 07-08 / 08$ & 0.229 & -0.055 \\
\hline ABL03 & $30 / 07-08 / 08$ & 0.287 & -0.087 \\
\hline ABL04 & $30 / 07-08 / 08$ & 0.320 & -0.093 \\
\hline ABL05 & $30 / 07-08 / 08$ & 0.331 & -0.037 \\
\hline ABL06 & $30 / 07-08 / 08$ & 0.264 & -0.111 \\
\hline ABL07 & $30 / 07-08 / 08$ & 0.256 & -0.058 \\
\hline ABL08 & $30 / 07-08 / 08$ & 0.246 & -0.095 \\
\hline ABL09 & $31 / 07-08 / 08$ & 0.224 & -0.038 \\
\hline ABL10 & $31 / 07-08 / 08$ & 0.281 & -0.029 \\
\hline ABL11 & $31 / 07-05 / 08$ & 0.633 & -0.348 \\
\hline$A B L 12$ & $31 / 07-10 / 08$ & 0.556 & -0.604 \\
\hline ABL13 & $31 / 07-04 / 08$ & 0.670 & -1.636 \\
\hline ABL14 & $01 / 08-10 / 08$ & 0.748 & -0.742 \\
\hline ABL15 & $01 / 08-10 / 08$ & 0.578 & -0.748 \\
\hline$A B L 16$ & $01 / 08-10 / 08$ & 0.583 & -0.866 \\
\hline ABL17 & $01 / 08-10 / 08$ & 0.678 & -0.847 \\
\hline$A B L 18$ & $01 / 08-10 / 08$ & 0.453 & -0.896 \\
\hline$A B L 19$ & $01 / 08-10 / 08$ & 0.350 & -1.293 \\
\hline$A B L 20$ & $01 / 08-10 / 08$ & 0.780 & -1.766 \\
\hline$A B L 21$ & $01 / 08-10 / 08$ & 0.793 & -1.557 \\
\hline$A B L 22$ & $01 / 08-10 / 08$ & 0.632 & -1.158 \\
\hline
\end{tabular}

